International Journal of English Literature and Social Sciences
Vol-6, Issue-4; Jul-Aug, 2021

Peer-Reviewed Journal

\title{
Representation of Cultural Values in the Novel Api Awan Asap by Korrie Layun Rampan
}

\author{
Devvi Agitha Anggi Ani, Herman J Waluyo, Nugraheni Eko Wardhani
}

Postgraduate Program of Indonesian Language Education, Sebelas Maret University, Surakarta, Indonesia

Received: 10 Jun 2021; Received in revised form: 06 Jul 2021; Accepted: 14 Jul 2021; Available online: 23 Jul 2021

(C)2021 The Author(s). Published by Infogain Publication. This is an open access article under the CC BY license

(https://creativecommons.org/licenses/by/4.0/).

\begin{abstract}
A good literary work is a literary work that can provide knowledge to its readers. One of the literary works that can provide knowledge to its readers is a novel. In literary works, especially novels, usually there are stories that contain good values for life, namely the problem of the nature of human relationships with other humans. The purpose of this study is to describe the cultural values contained in the novel Api Awan Asap by Korrie Layun Rampan. The form of this research is descriptive qualitative with content analysis method. Korrie Layun Rampan's novel entitled Api Awan Asap describes the cultural values contained in life, one of which is cultural values related to the nature of human relationships with each other.
\end{abstract}

Keywords - cultural values, literary anthropology, novel.

\section{INTRODUCTION}

Literary work is an overflow of the author's self-expression using the medium of language. Literary works created by a writer are fictitious, but based on the reality around the author. One of the most popular literary works is the novel. This is because the stories or narratives in the novel can be enjoyed and understood by all ages. According to Kosasih (2008: 54) a novel is an imaginative work that tells the whole side of the problems of the life of a person or several characters.

The essence of literature is storytelling. Storytelling is a form of creative art work performance about an event or event, the object of which is human, and using language as the medium (Wibowo, 2013:37). In line with Wibowo, Dewojati (2015:1) reveals that literary works are works of art, in the form of creative thinking. However, the reference to literary works is not the real world, but the fiction and imagination of the creative mind of a writer. This explains that literary works are the result of human creations using language, to obtain the aesthetics of language in making an interesting work.

Anthropology is a knowledge or study of human behavior. Anthropology views all parts of human culture and society as a combination of interacting variables. Therefore, literature is believed to be a mirror in the life of the people who support it. Moreover, literature is considered as the identity of a nation. Anthropology is divided into cultural anthropology, which is now developing into cultural studies (Ratna, 2013: 64). The meaning of Ratna's opinion above, anthropology is the study of human behavior and what is seen from all aspects of culture.

Research on the study of cultural values has been carried out by previous research including Suhardi \& Riauwati (2016) with objects of cultural values (Malay) in the oral literature of the people of Tanjung Pinang city, Ryan \& Endang (2016) with objects of shifting cultural values in the Bonai tribe, Yang Merdiatna (2019) with the object of cultural values in the Panjalu folklore, and Oki Desiana (2014) with a study of analysis of cultural values in the rantau novel.

Cultural values are something that cannot be separated from social conditions, also related to people's behavior in everyday life. Cultural values are always associated with beliefs that have been instilled since time immemorial, and passed down from generation to 
generation to the next generation. According to Koentjaraningrat (2009:153), the cultural value system describes the most basic stages of customs, which have been embedded in people's minds about the beliefs, behaviors, and habits of people's lives. Cultural values will always go hand in hand with the development of people's lives, so that it becomes a tradition that is difficult to replace with other cultural values.

Cultural values are abstract designs about a big and general problem that is very important and valuable for people's lives. These cultural values become a role model in the behavior of most members of the community concerned, are in their memories and are difficult to explain rationally. Cultural values are eternal, not easily changed and replaced with other cultural values (Abdul Latif, 2007: 35).

According to C. Kluckhohn (in Koentjaraninrat, 2015: 154) there are several basic problems in human life that form the basis for the framework of variations in cultural value systems, one of which is the problem of the nature of human relationships with each other. In their behavior, humans who live in a culture are guided by leaders, previous people, or superiors. Other cultures are more concerned with horizontal relationships between humans and each other. A person in a culture will feel dependent on others. These efforts are made to maintain good relations with others. This is something that is considered very important for life.

Seeing this proves that cultural values are very important for us as humans, considering that community culture is always associated with behavior in life that is never separated from the problem of the nature of human relationships with each other, who need each other, and help each other.

\section{METHOD}

This study analyzes the cultural values contained in the novel Api Awan Asap by Korrie Layun Rampan using the study of literary anthropology of Nyoman Kutha Ratna, and is expected to provide knowledge and an overview of the literary anthropology of Nyoman Kutha Ratna in analyzing the cultural values contained in the novel.

The form of this research is descriptive qualitative with content analysis method. Content analysis is a symbolic method because it is used to examine symbolic material (text) (Krippendorf, 2004: 15). The study of literature with an anthropological approach is a type of qualitative research. The research data using the Anthropological approach is in the form of verbal data, namely data obtained from exposure to the language of the character's statements in the form of dialogues and monologues as well as narratives in the novel Ceremony and Api Awan Asap by Korrie Layun Rampan.

\section{RESULTS AND DISCUSSION}

Based on research conducted by analyzing several sources, both books and reputable journals, it was found that the results of the analysis can be described by the researchers as follows. It can be explained that there are several cultural values in the Api Awan Asap novel, namely the problem of the nature of human relationships with each other:

"lou dibangun bukan karena warga tidak mampu membangun rumah sendiri-sendiri, tetapi, lou dibangung karena tradisi mengajarkan hidup bersama memberi manfaat yang lebih besar dari cara hidup orang perorang yang hanya mementingkan diri sendiri."

"Lalu?"

"Di dalam lou, setiap warga dapat langsung berkomunikasi setiap waktu, sehingga semua kesulitan dapat saling di bagi dan di ketahui warga lain." (Rampan, 2003:23-24)

The tradition in lou has been carried out from generation to generation since time immemorial, residents live side by side and gather to live their daily lives and help each other and share the same fate. This is done in order to maintain the ties of friendship. Lou residents are used to working together to deal with existing problems, if one of the residents is experiencing difficulties, other residents are happy to help with these difficulties and work together to solve them.

"Ya, itu wujud yang menyatukan. Tetapi mengenai dampak negatif dari cara komunal, seperti misalnya terserang wabah dan soal kesehatan masyarakat? soal kebakaran?"

"Soal itu telah diatasi selama berabad-abad. Tapi soal memelihara perasaan dan senasib sepenanggungan itu lebih penting (Rampan, 2003:25-26).

Based on the sentence above, it explains that human relations with each other are very important and commonplace in everyday life between individuals with one another, helping and needing each other is a tradition carried out by the people of Lou, they are used to living everything. The most important kinds of difficulties for them are facing common problems, sharing the same fate and caring for each other. Whatever the problem is big or small, the most important thing is to live together and help each other. 
Dengan perpaduan usaha yang dibangun Nori, lou Dempar menjadi pusat menyuplai segala kebutuhan warga di kota-kota kecamatan yang ada di sekitar situ. Lahan sayur-mayur yang luas dan sumber protein yang di dapat dari ikan dan unggas seperti ayam dan itik dapat dicukupi oleh warga yang ada disitu. Pada setiap rumah ladang selalu ada barak-barak kandang ayam dan itik, sehingga untuk kebutuhan ayam pedaging dan ayam kampung tercukupi. Demikian juga untuk telur dan bibit ayam maupun itik. Nori juga menyiapkan mesin tetas, membuat warga dapat menggunakannya tanpa membayar sewa. (Rampan, 2003: 112)

Nori as a resident of Lou village helps the activities of the residents starting from preparing all the food needs of the residents that he buys from a city far from Lou then he sells it at a shop making it easier for Lou residents who want to prepare their needs without having to go far to find ingredients to the city, then preparing a machine without having to pay for the rental of the machine with the aim of helping Lou residents, Nori does this so that Lou residents can carry out activities easily and quickly without having to pay so that the work done can be completed quickly and easily. Considering that Lou is a place far from urban areas, on the initiative of Nori, Lou residents feel helped by this.

Kau terlalu baik pada kami. Tak kutahu ada yang jahat padamu, selain kebajikan yang berlimpah dalam segala bantuan dan keringantanganmu pada Pune dan aku. Kau terlalu baik buat kami (Rampan, 2003: 131)

Nori feels that Sakatn is a good and responsible man and has no flaws in Nori's eyes. Sakatan often helps Nori in various activities, Nori feels that he does not deserve Sakatan because he feels that Sakatan is too good, he does not want to disappoint Sakatn's feelings. So he prefers to refuse every offer made by Sakatn, including an offer to propose to him.

\section{CONCLUSION}

From the description above, it can be concluded that the researcher found the cultural values contained in the story. These cultural values are part of the noble values of the nation's culture. Cultural values are also closely related to human relations with each other. Every human being has a good relationship between humans and each other, namely the relationship of mutual care and mutual help between fellow humans, this is done in order to make it easier if one person experiences difficulties then other people can help overcome the problem by working together, so that if one If you find a problem, you can solve it together. The severity or severity of a problem depends on how we respond to it and how the problem is solved together. The cultural values in the story also show the noble values of the nation's culture.

\section{ACKNOWLEDGEMENTS}

Thanks to Prof. (Em) Dr. Herman J. Waluyo, M.Pd. and Dr. Nugraheni Eko Wardhani, M. Hum. Who has guided and directed this research from beginning to end. Thank you to the editorial team and the journal team for giving us the opportunity to publish our research in this journal.

\section{REFERENCES}

[1] Dewojati, Cahyaningrum. (2015). Sastra Populer Indonesia. Yogyakarta: Gadjah Mada University Press.

[2] Krippendorf, K. (2004). Content Analysis, An Introduction to Its Methodology. California:Sage Publications.

[3] Kosasih, E. (2008). Apresiasi Sastra Indonesia.Jakarta: Nobel Edumedia.

[4] Koentjaraningrat. (2009). Pengantar Ilmu Antropologi. Jakarta: PT Rineka Cipta.

[5] Koentjaraningrat. (2015). Pengantar Ilmu Antropologi. Jakarta: PT Rineka Cipta.

[6] Latif, Abdul D. H. (2007). Pendidikan berbasis nilai kemasyarakatan. Bandung: PT Refika Aditama.

[7] Ratna, Nyoman Kutha. (2013). Teori, Metode dan Teknk Penelitian Sastra. Yogyakarta: Pustaka Pelajar.

[8] Wibowo, Agus. (2013). Pendidikan Karakter di Perguruan Tinggi. Yogyakarta: Pustaka Pelajar. 